The Journal of Public Space

ISSN 2206-9658

2018 | Vol. 3 n. 2

https://www.journalpublicspace.org

\title{
EDITORIAL
}

\section{The Public Voice}

Maggie McCormick

Adjunct Professor, RMIT University, Australia

Professor, Reutlingen University, Germany

maggie.mccormick@rmit.edu.au

\begin{abstract}
The Public Voice discusses art and activism in public space through the lens of how art practice is re-territoralising public space. The article begins with a consideration of both commissioned and uncommissioned works that challenge male dominance of public space while retaining a traditional relationship between the artist, art and the public. Through a discussion of 'relational' public practices from Relational Aesthetic to Community Art to Social Engagement, the article argues that the kind of 'relational' art and activism undertaken by the collectives, teams and individuals featured in this issue of The Journal of Public Space is linked by spatial practice as a conduit for social change. By framing their practice through a discussion around her own spatial public practice over time, the author emphasises the impact of urbanisation and digitalisation on the changing nature of public space and the public and how the public voice can be mapped through art and activism.
\end{abstract}

Keywords: public space voice, art, activism, urban, spatial, relational, mapping

To cite this article:

McCormick, M. (2018). The Public Voice. The Journal of Public Space, 3(2), 5-I2, DOI 10.3289I/jps.v3i2.11 07

This article has been accepted for publication in The Journal of Public Space. Please see the Editorial Policies under the 'About' section of the journal website for further information.

(C) (1) $\$$ This work is licensed under a Creative Commons Attribution - Non Commercial 4.0 International License https://creativecommons.org/licenses/by-nc/4.0/ 


\section{Activism and Public Space}

Activism can take many forms in public space from large scale public rallies to the individual on their soap box. Activism can be loud or quiet, bombastic or subtle. What links them all as activism is that the action sits outside of the routine of everyday public life. The action aims to disrupt the culture and patterns of public space and reveal it as a space where society's diversities converge, sometimes through the traces left as people negotiate their individual pathways through the space and sometimes through momentary mutual engagement through quick glances and snippets of conversation with a stranger. Art has the capacity to activate interventions in the public domain that interrupt this everyday social rhythm of the space, to create arrhythms that question perceptions embedded in that space, and claim it for the society of people who are the public space itself. Art activism creates moments that foster a new voice for public space.

This issue of The Journal of Public Space: Art and Activism in Public Space focuses on the voice of public space activated through the art practice of six collectives, teams and individuals working across a multiplicity of worldwide public spaces - Boa Mistura, Plastique Fantastique, inCOMMONS + limeSHIFT, Angélica Dass, Richard Briggs and Fiona Hillary. Together they form a snap shot of the bigger universal picture of the changing relationship between art practice, public space and the people within that space through a form of activism advocating that "public space in cities is a common good, meant to be open, inclusive and democratic - a right for everybody' as advocated by Luisa Bravo in her public lecture Stand Up for Public Space.' While global in their interventions and outcomes symptomatic of our time, each activation responds to the specificity of the space they are engaging with, while re-territoralising and re-conceptualising public space, its culture and art activism more generally.

\section{Public Space and Art Practice}

Traditionally public space has been seen as the city square or park land with its relationship to art through permanent monumental sculptures that recorded limited histories and through that process, claimed the space itself for a particular section of society. Today the nature of such art practice within public space is challenged as are the histories and ideologies, perceptions of people and place, traditionally embedded in these works. For example, this has resulted in public debates around the issue of retaining or removing traditional public sculptures that are now viewed as not representative of public views. A clear example of changing attitudes in the midst of such debates is the Fourth Plinth in Trafalgar Square in London UK. ${ }^{2}$ Three of the plinths hold statues of a male British general, a male army officer and a male royal. The fourth was also destined to hold a male royal but was held over due to lack of funds. A lucky misfortune. The fourth plinth on the square remained empty until around 1998 when a series of three commissioned works occupied the space. It was with the fourth temporary work Alison Lapper Pregnant 2005, a marble torso-bust by Mark Quinn, that the real challenge was made. ${ }^{3}$ While

\footnotetext{
I Luisa Bravo. Stand Up for Public Space, 2017. https://unhabitat.org/stand-up-for-public-space-luisa-bravo/

${ }^{2}$ Fourth Plinth, London UK. https://www.london.gov.uk/what-we-do/fourth-plinth-past-commissions \& https://www.bbc.com/news/uk-england-london-43565870

${ }^{3}$ Mark Quinn. Alison Lapper Pregnant. http://marcquinn.com/artworks/alison-lapper
} 
monumental in scale like the other three traditional sculptures, this work was of a person who was female, pregnant and born with no arms and shortened legs. Many other works have followed occupying the Fourth Plinth as a challenge to the historical symbolism of the public space of Trafalgar Square itself. A more detailed discussion around the public place that is Trafalgar Square can be read in Shanti Sumartojo's The Fourth Plinth: creating and contesting identity in Trafalgar Square, 2005-2010. ${ }^{4}$

While the Fourth Plinth example fall within officially accepted and commissioned challenges to the status quo, reflective of changing times and attitudes, other public activations are sometimes anonymous, unsanctioned and even illegal. One example of both commissioned and uncommissioned street works, symptomatic of the growing presence of strong female imagery in the public domain, are the paper paste ups of a Melbourne based street artist, Baby Guerrilla. ${ }^{5}$ Large scale black and white paste ups defy gravity and the assumptions of the space as they fly across that space and appear unexpectedly overnight on Melbourne's streets and laneways. Amongst others, Vexta and Swoon are two other women artists working in the public space of streets and lanes. Together they pose a re-territoralising of public space, as did Alison Lapper Pregnant in Trafalgar Square as a reclaiming voice that challenges white male dominance of these public spaces. Swoon sums this up by asking, 'Have we approached a tipping point in society, where, informed by the input of creative women, we begin to rewrite social narratives for the better?' in Roland Henry's Meet the Women Redefining Street Art. ${ }^{6}$

These examples taken from city squares and streets can be seen as disruptions to the accepted culture of specific public spaces and as such, a form of activism through art practice. While the outcomes create arrhythms in the social pattern of the space, the practice conforms to traditional modes of art making, in that people within the public space are seen as the audience, as observers. Many artists working in the public domain challenge this role of the public as observer. This is clearly evident in the public practice of all the artists included in this issue of The Journal of Public Space. Whether they work as individuals, teams, collectives or community facilitators, forms of 'relational' practice link their intent and art process. While their outcomes may vary, in one way or another they aim to engage the public beyond the role of audience so that the public and the space become an integral part of the art intervention itself, of the voice.

\section{Relational Art Practice and Activism}

Many people in the art world are familiar with the term 'relational aesthetics' coined by Nicolas Bourriaud in the 1990s to describe the tendency to make art based on, or inspired by, human relations and their social context. ${ }^{7}$ The role of the artist is proposed as a conduit between the audience and the event to create a social experience within a constructed environment. The event itself, what takes place between the participants, is

\footnotetext{
${ }^{4}$ Shanti Sumartojo. The Fourth Plinth: creating and contesting identity in Trafalgar Square, 2005-2010. Sage Journals. 2012. http://journals.sagepub.com/doi/abs/I0.1 I77//4744740 I2448304

${ }^{5}$ Baby Guerrilla, http://babyguerrilla.com/ \& https://blog.whodhavethought.com/2014/05/28/interview-babyguerilla

${ }^{6}$ Roland Henry. Meet the Women Redefining Street Art, The Guardian Australia, 8 January 2015. https://www.theguardian.com/artanddesign/2015/jan/07/street-art-women-elle-swoon-vexta

${ }^{7}$ Nicolas Bourriaud. Relational Aesthetics. Les presses du reel, France. 1998.
} 
seen as the work of art. Bourriaud's prime example is the Argentinian born Thai artist Rikrit Tiravanija who in one of his exhibitions cooked Thai food for visitors to the gallery to create an environment in which social exchange took place. The exchange is the art. While Bourriaud's 'relational aesthetics' was substantially referring to such changing practice within the gallery and institutional system, many artists working in the public domain had been working in a 'relational' way for some time, albeit labelled in different ways and often with different intentions. The Community Arts movement can be seen as a forerunner of the relational concept. Here a more traditional art outcome was usual, such as a mural or theatre piece, but the process and interaction between the artist and the public was viewed as equal in value. Early community led public art projects grew out of the idea of art as a democratic right that was very much grounded in a reterritoralising of both art practice and public space. The UK, USA and Australian examples were in this mode. During the 1960s, 1970s and into the 1980s many artists worked collaboratively within a participatory practice model within which art was made by the people themselves. In Melbourne the Community Arts Network embraced this mode of practice that I was a part of, working collaboratively on such large-scale projects as the Curtain Square Playground 1988. Symptomatic of its time the project engaged hundreds of local people in making and installing ceramic tiles that recorded their diverse connections to the Carlton neighbourhood and the creation of the character of its public domain. In this case the public space of the playground became a voice of the people. Other Community Arts Network public projects for example engaged poster art as part of political protest, again as a voice of the people. At the time, these examples were a form of radical activism through participatory democracy that rejected earlier efforts to 'take art to the people' though the model of educating the general public to appreciate the arts within art establishments. Owen Kelly's manifesto Community, art and the state: Storming the citadels $1984^{8}$ was symptomatic of this thinking about the role of art practice, public space, the people and the social and political framework of the times.

While still used as a definition of some practice, the term Community Art has lost its radical edge, its power and meaning in many places over time and we more often now refer to Social Engagement. The practice is diverse in its processes and outcomes and crosses over with concepts of community cultural development, placemaking, participatory art and social practice reflecting back to the social sculpture of Joseph Beuys. While socially engaged art practice defies a straight forward definition, a recent USA report, Mapping the Landscape of Socially Engaged Practice 2017 sets out some definitions. ' Included are 'belief in the agency and responsibility of art and artists' and 'artists working in collaboration'. While the report is somewhat America centric, these definitions do apply to the action of the artists included in this issue of The Journal of Public Space. Artists, architects, engineers, musicians, photographers, dancers, designers and the public are drawn together, as Boa Mistura say in this issue, with a common sense of 'responsibility with the city and the time we are in'. While the quote by William S. Burroughs at the start of the report may be debatable that 'Artists are the real architects

\footnotetext{
${ }^{8}$ Owen Kelly. Community, art and the state: Storming the citadels. Comedia, UK. 1984.

${ }^{99}$ Alexis Frasz \& Holly Sidford. Helicon Collaborative. Mapping the Landscape of Socially Engaged Practice. 2017. http://artmakingchange.org/wpcontent/uploads/2017/09/Mapping_the_Landscape_of_Socially_Engaged_Artistic_Practice_Sept2017.pdf
} 
of change, not the political legislators who implement change after the fact', creative activators within public space certainly play a pro-active part. While the report discusses how every major social movement throughout time has integrated art and activism, what is missing is consideration of the role of the space itself as a key component of art as activism in today's context.

\section{Spatial $=$ Social Practice}

What defines all included in Art and Activism in Public Space beyond most public practice loosely defined as Socially Engaged, is their direct 'relational' action with the public space itself, its building, objects and atmosphere, as a conduit to social inclusion and change.

This includes not only the practice of the collectives, teams and individuals featured in this issue but also to the projects the viewpoint - Canberra's first ever parklet by Natalia Weglarz and The urban lounge and a green view by Luisa Bravo. Both discuss the social impact of spatial interventions that re-interpret the parking space within the city environment.

All aim to reveal the public voice of the space in order to reveal its social voice. Each in their own way is engaged in spatial transformation, most often ephemeral, as an integral part of their social practice. Through this spatial practice each aims to foster shift and change through dialogue and challenge current social paradigms and in the process create a re-territorialisation of public space. This may well be reflective of their own diverse backgrounds, so that a multiplicity of arts, architecture and design inform each other to create a particular kind of urban practice responsive to the city itself. Cities have become central to our understanding of public culture and through this, an understanding of ourselves.

In this issue on Art and Activism in Public Space Boa Mistura redefine the power of the materials of art making and talk of promoting 'change through colour' though the paint's direct 'dialogue with the place' and how 'a layer of paint of barely a few millimetres thick can change the perception that a whole neighbourhood has of a place'. Richard Briggs also uses the material of art making to transform the space though, in his case, drawing materials. Through immersing himself in the cityscape and observing the people, buildings and objects that occupy that space his 'urban sketching' records multiple perceptions of a space. As he says, 'This approach to documenting the city can then be used to canvas a wider discussion on our built environment' and by default a rethinking of the possibilities of our shared public space. Like Richard Briggs, Plastique Fantastique address the built environment of public space. They use a sense of play to create a new surprising interface between the built environment of the space and its public. Through the introduction of ephemeral soft inflatable architecture into public space the space itself is challenged by what they call 'bewildering activities' of the new architectural interventions 'squeezing between buildings, squashing under bridges, entwining around lampposts or trees.' Notions of pleasure in public space also informs the workspace practice of inCOMMONS + limeSHIFT. They say, 'spatial transformation shifts the way people experience and engage'. When the space changes, social and cultural perceptions change. Imagination and possibilities enter the picture and as Fiona Hillary says, 'allow artists and audience to coconstitute the possibility of something other, triggering fleeting transformative acts of imagination'. Angélica Dass uses photography to explore and search out diverse identities 
through diverse colours across the portraits. The process reveals and asserts layered histories and cultures within the public domain through using the camera as a catalyst for a flow of dialogues in the space of streets. In the process people bring the space alive.

\section{Public Space Culture and Urban Practice}

Combined together, the voice of the public spaces these collectives, teams and individuals work in supports an important field of urban thinking that re-shapes public space culture. I describe this as a growing sense of urban citizenship or 'urbaness', a term I coined in my $\mathrm{PhD}$ thesis 2009 to describe a sense of being urban, being connected. ${ }^{10}$ In a rapidly urbanising world situated in a rapidly digitalising world it is important to activate public space in such a way that diverse voices shape our vision of the future. Fiona Hillary quotes Rosi Braidotti on this. Braidotti says, 'Whatever increases your capacity to act and intervene in the world - intervene in the public sphere - for the love of the world'." This reinforces the perspective of Luisa Bravo and Valerio Francia, City Space Architecture, when they say in relation to the 'We the People, We the Public Space' exhibition, the intention was 'to stress the concept that people and public space, intended as the space for democracy, social justice and equity, are strongly intertwined, so that talking about people is the same thing as talking about public space'. This can be extended to say that talking about public space is the same thing as talking about people - talking about public urban culture. All is reflected in the United Nations' campaign 'We the people' for the Global Goals launched in 2015 and the UN commitment 'Leaving no one behind' 2016 and 2017 for inclusive development quoted by Luisa Bravo.'2

This Overview is written in this context and framed by the perspective of many years of urban practice in and about public space, engaging in public culture as an artist, curator and academic researcher. As current Adjunct Professor and in my former role as Head of the Master of Arts (Art in Public Space) at RMIT University, Australia, I have published and presented on public space culture many times. My perspective on art and activism in public space has been shaped by my early innovative city space interventions in Melbourne from 1990 to 2006, as an artist and curator in public space that laid the groundwork for others to follow. In 1990 five important factors coincided - an economic downturn; artists' disillusionment with the commercial gallery system; a growing awareness of a new role for art in public space reflected in the City of Melbourne's fostering of art practice in the public domain; a general emerging understanding of the impact of urbanisation and digitalisation on art and activism. The economic downturn left many shop fronts and buildings in prime locations, empty. Combined with disillusionment with the commercial gallery system, the scenario opened up my interest in nonconventional city spaces as spaces for art action. Supported by the City of Melbourne and

\footnotetext{
${ }^{10}$ Maggie McCormick. The Transient City; mapping urban consciousness through contemporary art practice. Unpublished PhD thesis. Faculty of Architecture, Building and Planning, The University of Melbourne, Australia. 2009.

11 Rosi Braidotti. The First Supper Symposium paper. 2014. https://www.youtube.com/watch?v=BXbx_P7UVtE

${ }^{12}$ Bravo L. and Francia, V. (20I8). We the people, We the public space. An interactive exhibition at the 9th World Urban Forum. The Journal of Public Space. 3 (I), pp. 153-162. doi: https://doi.org/I0.5204/jps.v3il.325. https://www.journalpublicspace.org/article/view/325
} 
the National Association for the Visual Arts, I initiated No Vacancy in over ten empty shop fronts in one of Melbourne's prime city street and square locations on Collins and Swanston Streets. Over time the No Vacancy 1990-1994 concept grew to become urbanart that ran to 2006 and included claims on multiple public spaces across the city as locations for non-conventional art interventions. These included advertising panels at city tram stops, first floor windows, public stairwells and even a twelve-story empty building. I was not aiming to place conventional art in public space as alternative galleries, rather works designed by myself and others aimed to engage with the space itself and in particular with the reflective surface of glass windows and panels. The relationship between art and public was intertwined in this 'in-between' space to create a very different kind of active public art than the until then more familiar static public sculpture in the streets of Melbourne. Through the urbanart practice I went on to draw together global public city space through projects like Kultural Kommuting 1998 that linked public transport and public stairwell spaces in Berlin and Melbourne; melbourneconnectionasia 2004 that linked Melbourne public transport shelter spaces with gallery and artist run spaces across eight Asian cities; Global Fusion 2002 and Global Fusion Close Up 2006 that linked public spaces in Vienna and Melbourne. ${ }^{13}$ Experiences such as these heightened my awareness of the significance of public space and the power embedded in spatial art practice across global public space and people. My practice through urbanart while emerging out of the public space of Melbourne, took a global focus on urban space and the relationship of art practice to public space culture and urban identity by creating dialogues through establishing spaces for cultural translation amongst artists and between artists and the public.

The evolution of my public space practice from No Vacancy to urbanart paralleled the City of Melbourne's growing awareness of contemporary modes of art practice in public space that began with permanent contemporary works installed as Swanston Street Walk, to On Site with a series of temporary works installed in prime city public locations. The On Site catalogue 1990 sets out the intention of the works to 'explore, challenge, enhance and transform our interpretation of the city'. The key word here is - 'transform'. The power of temporary installations integrated into the fabric of the city itself became the City of Melbourne's mantra over many years as the Melbourne Laneway projects 200I - around 2010 and was adopted by the City of Sydney 2008-2013 and others. ${ }^{14}$

\section{Mapping the Public Voice}

My interest in public space is currently around the public space culture of Skype, the impact of mediation of digital screens on urban identity and what role art practice plays in shaping and mapping this. The connectedness of urban public space and a common sense of being urban, or what I call 'urbaness', brought about through urbanisation and digitalisation, is now a key factor in my artistic and curatorial practice in public space in particular through the lens of the co-curated project SkypeLab (20I4 ongoing) and its

\footnotetext{
${ }^{13}$ urbanart. National Library of Australia. Pandora Australia's Web Archive. http://pandora.nla.gov.au/tep/2I443

${ }^{14}$ City of Melbourne does not hold an online archive. City of Sydney. Laneway/City Spaces. http://www.cityartsydney.com.au/projects/lanewaycity-spaces/
} 
predecessor, Skypetrait (2012-2013). ${ }^{15}$ I wrote about these concepts in more detail in Skypeography. Investigating and mapping the public mind space of urbaness in The Journal of Public Space 2018. ${ }^{16}$ I discuss how mediation by screens is creating new urban concepts across an emerging new spatial geography and its emerging sociologies and cartographies. Unlike my earlier public space practice, my current artistic and curatorial practice is primarily a mapping practice recording my urban cartography through works with titles such as MelBeiVien, MelShangLingen and MelLingen. ${ }^{17}$ Each records my personal voice through the interconnected urban public space culture of Vienna, Beijing, Shanghai, Reutlingen and Melbourne. My voice can be seen as one amongst many diverse voices. While the voice of the collectives, teams and individuals in this issue of The Journal of Public Space: Art and Activism in Public Space is present in their practice, they do not specifically set out to address their personal voice but rather use their spatial practice to draw out the diverse, common or universal voice. While they are not engaged directly with the new digital public space, their physical activations expand across a network of global spaces, mapped through their web presence and in the process create a global cartography of the re-territoralising of the public voice through art and activism.

\footnotetext{
${ }^{15}$ Maggie McCormick and Henning Eichinger. Skypetrait and SkypeLab. www.skypelab.org

${ }^{16}$ McCormick, M. (2018). Skypeography. Investigating and mapping the public mind space of urbaness. The Journal of Public Space, 3 (I), pp. 3-12. doi: https://doi.org/I0.5204/jps.v3il.315. Abstract https://www.journalpublicspace.org/article/view/315 \& article https://www.journalpublicspace.org/article/view/3/5/303

17 Maggie McCormick. MelShangLingen and Mellingen can be viewed on pages 42-45 and pages 64 and 65. SkypeLab: transcontinental faces and spaces. Kerber. Germany, USA, 2016. http://www.skypelab.org/publication/
} 